\title{
Improvement of annual forage and seed production in the sub-humid zone of Nigeria through supplement irrigation
}

\section{J.O. AKINOLA*, A.A. ADDO**, and K.C. OLUFOKUNBI***}

* Department of Animal Science, Faculty of Agriculture, Ahmadu Bello University, P.M.B. 1044, Zaria, Nigeria

** Department of Vocational and Technical Education, Faculty of Education, Ahmadu Bello University, Zaria, Nigeria

*** Department of Agricultural Economics, Obafemi Awolowo University, Ile-Ife, Nigeria

\begin{abstract}
A two-year study was conducted at Shika in the Northern Guinea Savanna of Nigeria to evaluate several perennial and annual forage species for seasonal and total annual herbage and/or seed production. Over the entire experimental period, total dry matter (DM) yields for grasses, perennial and hay-suited annual legumes varied from 27.5 to $79.1,18.8$ to 40.3 and 40.5 to $50.5 \mathrm{t} / \mathrm{ha}$, to which irrigation contributed 48 to 66,50 to 57 and $56 \%$ respectively. Irrigated grass crude protein (CP) contents averaged 5.3 and $9.9 \%$; and legume CP contents 16.1 and $18.8 \%$ for the May and December harvests while rainfed grass CP contents ranged from $7.7 \%$ (August) to $10.9 \%$ (October), the corresponding legume values being 18.7 and $20.9 \%$.

Irrigated cropping accounted for 55 to $56 \%$ of the 9207 to $12461 \mathrm{~kg} /$ ha seed yield recorded in dual purpose legumes. It was inferred that on the basis of total herbage yield, distribution of yield and responsiveness to irrigation Pennisetum purpureum, Brachiaria decumbens, Cajanus cajan Acc UQ 50 or 3D 8104 and S. guianensis cv Cook proved to be promising; reasonable seed yield levels were obtained from $C$. cajan 3D 8104, Glycine max Acc. 49-14 and M 216 and Vigna unguiculata Acc Ivu 1283, whether irrigated or rainfed. The potential of irrigation is discussed in relation to feed, food and livestock production.
\end{abstract}

Index words: irrigation, tropical legumes and grasses 


\section{Introduction}

For the past 27 years, and more especially since the late 1970's, it has proved increasingly difficult for Nigeria to provide even a quarter of the minimum animal protein requirements of her teeming population despite the substantial agricultural potential in terms of land, climate and human resources. While there has been a marked shortfall in the national gross protein supply, animal based protein percentage of the human diet has also continually diminished. Computed animal protein supply declined from 8.6 grams daily per caput in 1968 to 6.5 grams in 1980 and below 6.0 grams in 1985. These figures represent about 25 to 17 per cent of the minimum daily animal protein intake recommended by the British Medical Association.

Accurate human and livestock population figures for Nigeria are presently unavailable. However, human population tends to increase more rapidly (presumably because of the phenomenally high birth rates particularly in the rural areas and comparatively low average death rates due to considerably improved primary health care delivery). Based on a projected 2.5-3.2 per cent annual growth rate, this may rise from an estimated 84.9 million in 1984 (Oloruntoba, 1984) to about 134.0 million by the end of the century. On the other hand, the supply of livestock products by the country's estimated 9.3 million head of cattle (some authorities quote 11 to 15 million), 8.8 million sheep, 20.8 million goats, 0.86 million pigs and 133.5 million poultry grows only at a rate of about 0.75 per cent annually. Hinged on the above, it is expected that the livestock population level ought to satisfy the country's animal protein needs but, would be found deficient when translated into performance and livestock units, because of serious inefficiencies in the current livestock production systems. Since the overall annual requirement of animal products grows at a rate of 5 per cent, a rather wide gap thus exists between the domestic supply and demand, a discrepancy which cannot be taken care of even by 1992 , unless the supply of animal products grows at an unprecedented annual raie higher than 11 per cent.

A major constraint on livestock production is the perennial feed shortage, especially during the drier part of the year. The Fulani pastoralists, who account for over 90 per cent of Nigeria's cattle population, depend almost exclusively on the natural grasslands and an extensive system of management. Notable characteristics of this include: the use of unimproved and low yielding native grasses; striking seasonal fluctuations in the quantity and quality of available forage to the extent that overgrazing, severe liveweight losses and in fact high mortality occur during the dry season; livestock owners' greater interest in the numerical strength than in the care of their livestock; lack of provision for supporting grazing during droughts and long dry seasons with supplements such as crop residues, agroindustrial by-products and/or high quality feed reserves; shortage of water and mineral licks. Other bottlenecks comprise tse-tse fly infestation particularly in the humid zone; manipulation of predominantly unproductive livestock breeds and generally inadequate veterinary care and services.

The hectarage on hand for livestock grazing in Nigeria is decreasing rapidly, possibly as a result of a combination of factors such as mounting population pressure, urbanization, industralization, land use for crop production and other agricultural programmes and, desert encroachment. New strategies therefore have to be devised and developed for improving land meant for agro-pastoralism to match the much needed high output of animal products per animal and per hectare. This is in addition to breeding and utilizing highly productive animals, sizably raising the level of livestock husbandry and applying optimal feeding regimes.

One feasible logistic is the integration of irrigated forage production into the overall land use package for improving the plane of animal nutrition and hence increasing not only meat and milk output but also the degree of 
animal resistance to attack by pests and diseases.

The Federal Government of Nigeria, upon realising the need to make more land cultivable, increase crop yields per hectare through a more efficient production system and guarantee sufficient agricultural raw materials for the country's rapidly developing industries, decided to set-up large irrigation schemes under several River Basin and Rural Development Authorities (RBRDAs). These Authorities were mandated to exploit, harness and manage the country's water resources with the objective of extenuating drought effects and raising all-inclusive agricultural productivity, among other things. More unambiquously, land would be cultivated for the production of crops and livestock both within and outside the irrigation schemes. Although this implicates the production of forage crops, at best irrigation efforts have been concentrated on cereal crops and the residue made available for livestock feeding.

Investigations in the subhumid zone of Nigeria (de Leeuw, 1972; Akinola, 1975) demonstrated the potential for forage production under dry season irrigation conditions. These studies suggested the need for long-term research on the yield responses of forage species to irrigation and different agronomic practises with a view to removing the constraints of chronic dry season scarcity of supplementary feeds.

This paper presents the results of experiments conducted over a two-year period to examine a number of forage crops for seasonal and total annual herbage and seed yields when grown under rainfed and dry season irrigated situations. The speculation was that the findings might help in the development of irrigation assisted forage production programmes, which would alleviate the problem of dry season feed shortages particularly in the subhumid and drier zones of Nigeria.

\section{Materials and methods}

\section{Location}

The experimental location was a low-lying area of the National Animal Production Research Institute (NAPRI), Shika (latitude $11^{\circ} 12^{\prime} \mathrm{N}$, longitude $\left.7^{\circ} 33^{\prime} \mathrm{E}\right), 22 \mathrm{~km}$ north-east of Zaria in the Northern Guinea Savanna of Nigeria. The dry season lasts approximately from October to April while July to September accounts for two-thirds of the $1034 \mathrm{~mm}$ long-term (1929-1976) mean annual rainfall. The study years contrasted in rainfall intensity and distribution as demonstrated by the occurrence of $857 \mathrm{~mm}$ from April to September in 1975 and $1284 \mathrm{~mm}$ between April and October in 1976. Mean maximum and minimum temperatures vary between $35.2 / 21.3^{\circ} \mathrm{C}$ (April) and $27.1 / 12.0^{\circ} \mathrm{C}$ (January). Mean relative humidity ranges from $15.2 \%$ in January-February to $75.4 \%$ in July-August while sunshine hours decline from 9.4 in November to 5.6 in August.

Analysis showed that the $0-15 \mathrm{~cm}$ horizon of the sandy clay loan soil, hitherto followed, was characterised a $\mathrm{pH}\left(\mathrm{H}_{2} \mathrm{O}\right)$ of $6.2 ; 1.24 \%$ organic matter; $0.085 \%$ total nitrogen; 0.40 $\mathrm{kg} / \mathrm{ha}$ water extractable phosphorus; and $1.33,3.56,0.38$ mequiv. exchangeable magnesium, calcium and potassium $100 \mathrm{~g}$, respectively.

\section{Land preparation}

On 30 December 1974, the land which had been cleared and two days earlier flood irrigated, was disc-ploughed and harrowed twice. Following compound fertilizer $\left(20 \mathrm{~N}: 10 \mathrm{P}_{2} \mathrm{O}_{5}\right.$ : $10 \mathrm{k}_{2} \mathrm{O}$ ) application by hand broadcast at the rate of $377 \mathrm{~kg} / \mathrm{ha}, 60 \mathrm{~cm}$ ridges were made and the furrows filled with irrigation water (Doorn van, 1972). At the start of the second cropping year (December 1975) this level of fertilizer was again applied. 


\section{Experimental design}

Three experiments were laid down, each in a randomized complete - block design with three replicates, for species herbage and/or seed yield comparisons under rainfed and irrigated conditions. A plot measured $6 \mathrm{~m} \times$ $4.2 \mathrm{~m}$ and was separated lengthwise from the next by a metre-wide gap, and, breadthwise by an unplanted ridge while blocks were demarcated by bunds.

\section{Planting and management}

Details of the plant species studied are presented in Table 1. Local Cajanus cajan accession is tall, late maturing and acropetal in the flower development pattern whereas

Table 1. Species, immediate origin and sowing rates.

\begin{tabular}{lcc}
\hline Species & $\begin{array}{c}\text { Immediate } \\
\text { origin }\end{array}$ & $\begin{array}{c}\text { Sowing } \\
\text { rate }(\mathrm{kg} / \mathrm{ha})\end{array}$ \\
\hline
\end{tabular}

\section{Experiment 1 - Perennial grasses and legumes for herbage production}

\section{Grasses (Perennials)}

Andropogon gayanus (Gamba)

Brachiaria decumbens (Signal)

Cenchrus ciliaris cv Biloela (Buffel)

Chloris gayana cv Callide (Rhodes)

Digitaria smutsii (Woolly finger)

Panicum maximum var Trichoglume (Green panic)

Pennisetum purpureum (Elephant cv Ngala)

Pennisetum purpureum (Elephant cv Shika)

$\begin{array}{ll}\mathrm{S} & 50^{*} \\ \mathrm{~S} & \mathrm{~V} \\ \mathrm{Q} & 7.5 \\ \mathrm{~S} & 7.5 \\ \mathrm{~S} & \mathrm{~V} \\ \mathrm{Q} & 7.5 \\ \mathrm{~S} & \mathrm{~V} \\ \mathrm{~S} & \mathrm{~V}\end{array}$

Legumes (Short-lived perennials)

Cajanus cajan (Pigeonpea) Acc Local

Cajanus cajan (Pigeonpea) Acc. 3D 8104

Cajanus cajan (Pigeonpea) Acc. UQ 50

$\begin{array}{ll}\text { M } & 25 \\ \text { I } & 25 \\ \text { Q } & 25\end{array}$

\section{Legumes (Perennials)}

Centrosema pubescens (Centro)

Desmodium scorpiurus (Samoan clover)

Desmodium uncinatum cv Silverleaf (Silverleaf desmodium)

Neonotonia wightii cv Cooper (Cooper glycine)

Macroptilium atropurpureum cv Siratro (Siratro)

Stylosanthes guianensis cv Cook (Cook stylo)

$\begin{array}{ll}\mathrm{S} & 10 \\ \mathrm{~S} & 7.5 \\ \mathrm{Q} & 7.5 \\ \mathrm{Q} & 10 \\ \mathrm{Q} & 10 \\ \mathrm{Q} & 7.5\end{array}$

\section{Experiment 2 - Hay-suited annual legumes for herbage production}

Glycine max (Soybean) var Congo Yellow

Glycine max (Soybean) var Malayan

Glycine max (Soybean) var Potchefstroom 55

Vigna unguiculata (Cowpea) Acc. Ivu 1283

$\begin{array}{ll}\text { M } & 45 \\ \text { M } & 45 \\ M & 45 \\ \text { I } & 25\end{array}$

Experiment 3 - Short-lived perennial and annual legumes for seed production

Cajanus cajan (Pigeonpea) Acc. 3D 8104

Glycine max (Soybean) var Improved Pelican

I 20

Glycine max (Soybean) Acc 49-14

Glycine max (Soybean) Acc M 216

Vigna unguiculata (Cowpea) Acc Ivu 1283

\footnotetext{
* Seed with involucre sown.
}

$\mathrm{V}=$ Vegetatively established.

I = International Institute of Tropical Agriculture, Ibadan, Nigeria .

$\mathrm{Q} \quad=$ University of Queensland, Queensland, Australia.

M\&S = Mokwa and Shika Stations of the Institute for Agricultural Research, Ahmadu Bello University, Zaria, Nigeria. 
the $C$. cajan accessions 3D 8104 and UQ 50 are intermediate and basipetal (AKINOLA and Whiteman, 1972). Except the $C$. cajan accessions used, Glycine max and Vigna unguiculata which had no problem of hardseededness, all legumes were scarified with concentrated sulphuric acid before inoculation with the appropriate Rhizobium strain. Seeds were drilled in shallow $(1-3 \mathrm{~cm})$ grooves on ridge tops at rates depending on size, germinability and intended use or sprigs planted $30 \mathrm{~cm}$ apart within the ridge on 2 January, 1975. Irrigation was supplied once weekly from November to May unless over $25 \mathrm{~mm}$ rain fell shortly before the scheduled irrigation date.

\section{Experiment 1}

No subsequent weeding was necessary after that carried out on 20 February, 1975. Herbage dry matter (DM) yield estimates were based on the inner $4.8 \mathrm{~m} \times 3 \mathrm{~m}$ of each plot, the rest being cut and discarded on the dates shown in Table 2. Thus irrigated dry season periods of growths and regrowths totalled 209 and 207 days while rainfed wet season

Table 2. Dry matter yields ( $\mathrm{t} / \mathrm{ha}$ ) of irrigated and rainfed perennial grasses and legumes.

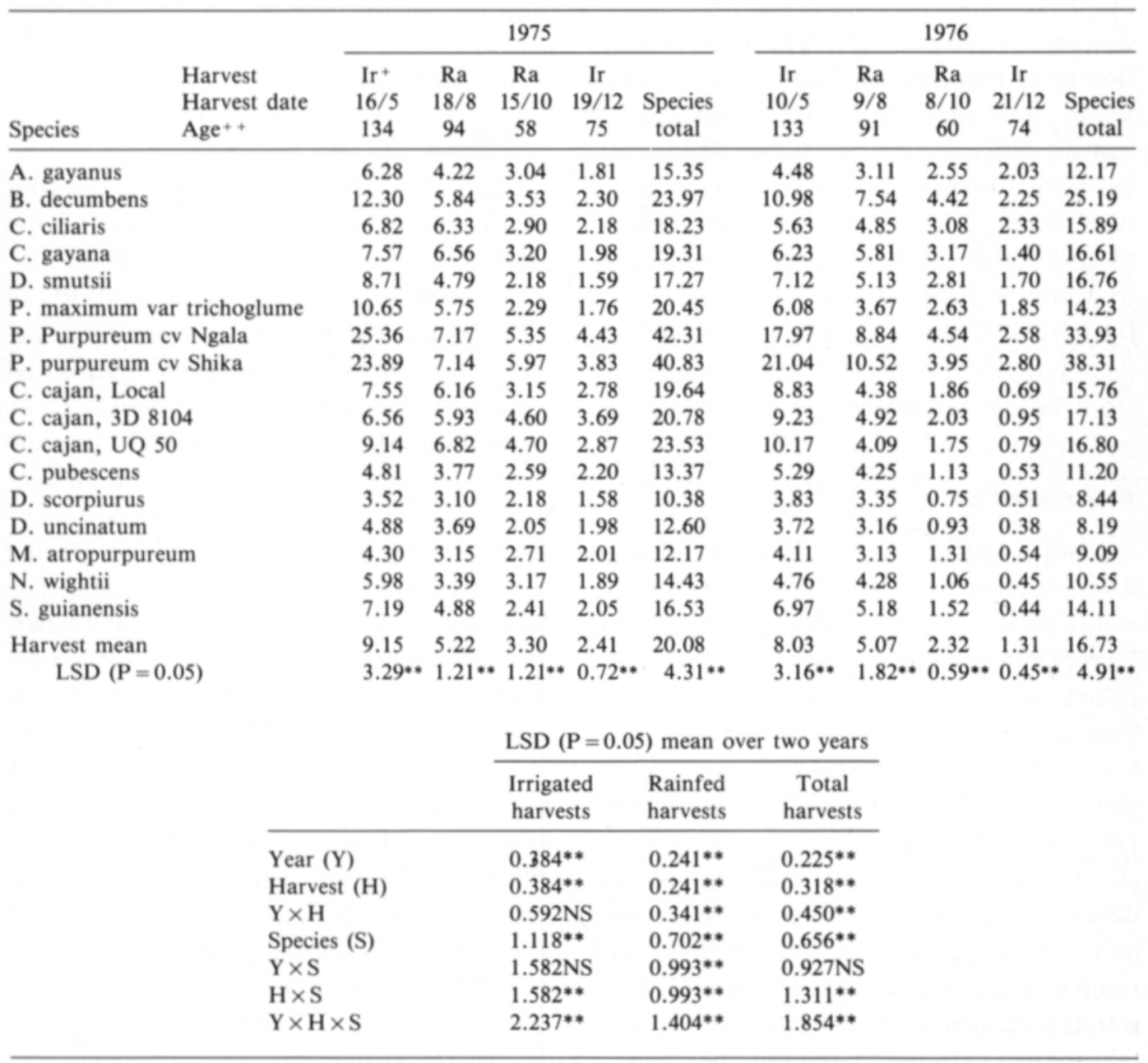

+ Ir, Ra $=$ Irrigated and rainfed harvests.

++ Days from planting $(16 / 5 / 75$ only) or cut back.

NS $=$ Non-significant at $\mathrm{P}=0.05 ; * *$ Significant at $\mathrm{P}=0.01$. 
periods amounted to 151 and 152 days in 1975 and 1976, respectively. Harvesting was with the hand sickle and cutting heights above the ridge top were $30 \mathrm{~cm}$ for $C$. cajan, $20 \mathrm{~cm}$ for Andropogon gayanus and Pennisetum purpureum, and $15 \mathrm{~cm}$ for the remaining species. The harvested material was weighed, subsampled, oven-dried at $80^{\circ} \mathrm{C}$ for 48 hours, milled and analysed for crude protein ( $\mathrm{CP}=$ $\mathrm{N} \% \times 6.25$ ) content (AOAC, 1970) on plot basis.

\section{Experiment 2}

Ridges were weeded, cleared of trash and remoulded prior to each of the second, third and fourth sowings on 17 July 1975, 18 December 1975 and 22 July 1976. Each production cycle required one hand weeding. Harvesting and sampling for DM yield and CP content determination were as described in $\mathrm{Ex}$ periment 1 except that plants were cut at the cotyledonary node. Days to hay stage, defined as time of first filled pod changing from green to yellow in $50 \%$ of plants, varied from 85 (G. max var Congo Yellow and $V$. unguiculata Acc. Ivu 1283) to 115 for July sowings and from 120 to 140 for December sowings.

\section{Experiment 3}

Land preparation procedures and sowing dates in respect of $G$. max and $V$. unguiculata were similar to those outlined for Experiment 2 crops above. The G. max examined comprised relatively early (day 100) Improved Pelican and intermediate (day 116) maturing accessions 49-14 and M216. These days to maturity relied on Shika data during normal growing season. Harvesting for seed yield occurred when 90 to $95 \%$ of filled pods had desiccated and were recorded as April/May and end of October for the irrigated and rainfed crops, respectively. C. cajan 3D 8104 stands remained in the plots from the trial establishment to termination but were cut back to $30 \mathrm{~cm}$ after each pod harvest in June (irrigated) and December (rainfed).
At harvest, reproductive branches were cut with hand sickles, sundried for three to four days and threshed. Sub-samples from the seeds recovered were dried to constant weight in hermetically sealed glass desiccator jars for seed yield determination and analysed for CP content (See Experiment 1) - G. $\max$ CP content being derived from the formula $\mathrm{CP}=$ N\% $\times 5.71$ (WATt and Merrill, 1963).

\section{Statistical analysis}

Statistical analysis of the data was carried out as described by STEEL and TORRIE (1960).

\section{Results}

\section{Experiment 1}

\section{Dry matter yield}

The DM yields for four irrigated and four rainfed harvests during the two experimental years are presented in Table 2. Total DM yields were significantly higher $(\mathrm{P} / 0.01)$ in 1975 (except for Brachiaria decumbens) despite the higher 1976 rainfall, 1976 grass and legume yields being lower by 12.5 and $22.5 \%$ respectively. DM yields maximised in May and declined significantly with subsequent harvests to a December lowest so that the pooled irrigated harvests far out-yielded the rainfed harvests. Significant species DM yield differences occurred between years and among harvests within a year. Over both years, the Pennisetum purpureum cultivars gave the highest grass DM yields (cv Ngala 76.24 and cv Shika $79.14 \mathrm{t} / \mathrm{ha})$, followed by $B$. decumbens $(49.16$ $\mathrm{t} / \mathrm{ha})$ with the lowest $(27.52 \mathrm{t} / \mathrm{ha})$ resulting from A. gayanus. For the legumes, Stylosanthes guianensis DM yield $(30.64 \mathrm{t} / \mathrm{ha})$ ranked next to the Cajanus cajan Acc. yields ( 35.40 to $40.33 \mathrm{t} / \mathrm{ha})$, the lowest $(18.82 \mathrm{t} / \mathrm{ha})$ for Desmodium scorpiurus being, however, non-significantly different $D$. uncinatum and Macroptilium atropurpureum yields.

Irrigated grass harvests contributed $48 \%$, through $59 \%$ to approximately $66 \%$ of the 
two-year total DM yields for Chloris gayana (lowest), Panicum maximum var Trichoglume and $P$. purpureum respectively. The corresponding legume figures were $50 \%$ for $D$. scorpiurus, $54 \%$ for $S$. guianensis and 54 to $57 \%$ for the $C$. cajan accessions. Unlike other swards, B. decumbens total annual DM yield was higher in 1976 in 1976 because of better May-October growth compared with the related 1975 period. In only Cenchrus ciliaris and C. gayana were irrigated harvest yields equal to or less than rainfed harvest yields.

\section{Crude protein content}

Average annual and harvest by harvest CP contents for all species are summarised in $\mathrm{Ta}$ ble 3. CP contents were similar for both years but were significantly affected by harvest. Harvests taken in May had the lowest average CP contents, followed by those taken in August, December and October, irrespective of year. Legumes CP contents doubled those of the grasses, which resulted in the highly significant species differences encountered. Irrigated grass $\mathrm{CP}$ contents averaged $5.3 \%$ and

Table 3. Crude protein contents ( $\%$ dry matter) of irrigated and rainfed perennial grasses and legumes.

\begin{tabular}{|c|c|c|c|c|c|c|c|c|c|c|c|c|}
\hline \multirow[b]{4}{*}{ Species } & \multirow{3}{*}{\multicolumn{2}{|c|}{$\begin{array}{l}\text { Harvest } \\
\text { Harvest date }\end{array}$}} & \multicolumn{5}{|c|}{1975} & \multicolumn{5}{|c|}{1976} \\
\hline & & & $\mathrm{Ir}^{+}$ & $\mathrm{Ra}$ & $\mathrm{Ra}$ & Ir & & Ir & $\mathrm{Ra}$ & $\mathrm{Ra}$ & Ir & \\
\hline & & & $16 / 5$ & $18 / 8$ & $15 / 10$ & $29 / 12$ & & $10 / 5$ & $9 / 8$ & $8 / 10$ & $21 / 12$ & \\
\hline & $\mathrm{Age}^{++}$ & & 134 & 94 & 58 & 75 & Mean & 133 & 91 & 60 & 74 & Mean \\
\hline \multicolumn{3}{|l|}{ A. gayanus } & 5.1 & 8.6 & 12.3 & 12.0 & 9.5 & 5.8 & 8.5 & 11.7 & 10.7 & 9.2 \\
\hline \multicolumn{3}{|l|}{ B. decumbens } & 5.4 & 7.4 & 10.8 & 9.8 & 8.4 & 5.3 & 7.9 & 11.0 & 10.3 & 8.6 \\
\hline \multicolumn{3}{|l|}{ C. ciliaris } & 5.2 & 7.6 & 10.3 & 8.8 & 8.0 & 6.0 & 7.9 & 10.0 & 9.4 & 8.3 \\
\hline \multicolumn{3}{|l|}{ C. gayana } & 5.3 & 6.3 & 9,8 & 9.8 & 7.8 & 5.5 & 8.1 & 10.4 & 9.9 & 8.5 \\
\hline \multicolumn{3}{|l|}{ D. smutsii } & 5.6 & 8.0 & 12.2 & 10.5 & 9.1 & 5.0 & 7.8 & 11.6 & 11.0 & 8.9 \\
\hline \multicolumn{3}{|c|}{ P. maximum var trichoglume } & 5.1 & 7.5 & 10.7 & 9.5 & 8.2 & 5.2 & 8.2 & 10.2 & 9.2 & 8.2 \\
\hline \multicolumn{3}{|c|}{ P. purpureum cv Ngala } & 4.9 & 7.5 & 11.7 & 9.3 & 8.3 & 5.1 & 6.3 & 10.2 & 9.4 & 7.8 \\
\hline \multicolumn{3}{|c|}{ P. purpureum cv Shika } & 4.8 & 7.9 & 11.6 & 9.9 & 8.6 & 5.0 & 6.5 & 9.9 & 9.3 & 7.7 \\
\hline \multicolumn{3}{|l|}{ C. cajan, Local } & 15.5 & 16.9 & 21.3 & 19.0 & 18.2 & 14.8 & 17.2 & 19.7 & 18.7 & 17.6 \\
\hline \multicolumn{3}{|c|}{ C. cajan, 3D 8104} & 16.8 & 17.8 & 19.8 & 19.3 & 18.4 & 16.1 & 18.6 & 20.5 & 20.0 & 18.8 \\
\hline \multicolumn{3}{|c|}{ C. cajan, UQ 50} & 16.3 & 18.3 & 19.8 & 18.8 & 18.3 & 15.5 & 17.9 & 19.3 & 19.5 & 18.1 \\
\hline \multicolumn{3}{|l|}{ C. pubescens } & 15.9 & 17.3 & 21.5 & 19.0 & 18.4 & 15.4 & 18.1 & 21.7 & 19.5 & 18.7 \\
\hline \multicolumn{3}{|l|}{ D. scorpiurus } & 16.9 & 20.6 & 22.6 & 21.6 & 20.5 & 17.3 & 21.8 & 23.8 & 22.5 & 21.4 \\
\hline \multicolumn{3}{|l|}{ D. uncinatum } & 14.7 & 17.0 & 18.6 & 17.9 & 17.1 & 13.9 & 16.3 & 18.1 & 17.6 & 16.5 \\
\hline \multicolumn{3}{|c|}{ M. atropurpureum } & 16.3 & 19.4 & 23.5 & 21.9 & 20.3 & 15.8 & 20.0 & 21.4 & 20.1 & 19.3 \\
\hline \multicolumn{3}{|l|}{ N. wightii } & 18.2 & 21.3 & 22.0 & 21.1 & 20.7 & 18.8 & 20.8 & 22.5 & 22.2 & 21.1 \\
\hline \multicolumn{3}{|l|}{ S. guianensis } & 15.6 & 18.1 & 20.3 & 19.3 & 18.3 & 16.3 & 17.7 & 20.9 & 20.3 & 18.8 \\
\hline \multirow{11}{*}{\multicolumn{2}{|c|}{$\begin{array}{l}\text { Harvest mean } \\
\qquad \text { LSD }(P=0.05)\end{array}$}} & & 11.0 & 13.4 & 16.4 & 15.1 & 14.0 & 11.0 & 13.5 & 16.0 & 15.1 & 13.9 \\
\hline & & & $2.18 * *$ & * 2.77 & ** 3.07 & $* 2.26^{*}$ & $* 1.67 * *$ & $2.33 * *$ & $2.81 * *$ & $2.70 *$ & $3.77 * *$ & $2.34 * *$ \\
\hline & & & & & \multicolumn{5}{|c|}{ LSD $(P=0.05)$ mean over two years } & & & \\
\hline & & & & & \multicolumn{2}{|c|}{$\begin{array}{l}\text { Irrigated } \\
\text { harvests }\end{array}$} & $\begin{array}{l}\text { Rainfed } \\
\text { harvests }\end{array}$ & \multicolumn{2}{|c|}{$\begin{array}{c}\text { Total } \\
\text { harvests }\end{array}$} & & & \\
\hline & & \multicolumn{2}{|c|}{ Year $(Y)$} & & \multicolumn{2}{|c|}{$0.521 \mathrm{NS}$} & $0.472 \mathrm{NS}$ & 0.328 & $8 \mathrm{NS}$ & & & \\
\hline & & Harve & $(\mathrm{H})$ & & 0.521 & $1^{* *}$ & $0.472^{* *}$ & 0.46 & $4^{* *}$ & & & \\
\hline & & $\mathrm{Y} \times \mathrm{H}$ & & & 0.737 & $7 \mathrm{NS}$ & $0.668 \mathrm{NS}$ & $0.65 t$ & $6 \mathrm{NS}$ & & & \\
\hline & & Specie & (S) & & 1.520 & $0^{* *}$ & $1.377^{* *}$ & 0.95 & $7 * *$ & & & \\
\hline & & $\mathrm{Y} \times \mathrm{S}$ & & & 2.149 & $9 \mathrm{NS}$ & $1.948 \mathrm{NS}$ & 1.35 & $3 \mathrm{NS}$ & & & \\
\hline & & $\mathrm{H} \times \mathrm{S}$ & & & 2.149 & $9 * *$ & $1.948 \mathrm{NS}$ & 1.91 & 4NS & & & \\
\hline & & $\mathrm{Y} \times \mathrm{H}$ & & & $3.03 \mathrm{~s}$ & $9 \mathrm{NS}$ & $2.755 \mathrm{NS}$ & $2.70 t$ & $6 \mathrm{NS}$ & & & \\
\hline
\end{tabular}

$+\mathrm{Ir}, \mathrm{Ra}=$ Irrigated and rainfed harvests.

++ Days from planting $(16 / 5 / 75$ only) or cut back.

$\mathrm{NS}=$ Non-significant at $\mathrm{P}=0.05 ; * *$ Significant at $\mathrm{P}=0.01$. 
$9.9 \%$, and legumes, $16.1 \%$ and $18.8 \%$, for the May and December harvests respectively. Average rainfed grass CP contents varied from $7.7 \%$ (August) to $10.9 \%$ (October), the corresponding values for the legumes being $18.7 \%$ and $20.9 \%$. The two $P$. purpureum cvs and $P$. maximum var tichoglume maintained the lowest CP contents under irrigated, and $A$. gayanus and $D$. smutsii the highest, whether irrigated or rainfed. Legume CP contents increased from low for D. uncinatum, through $S$. guianensis and $C$. cajan, to high for D. scorpiurus and Neonotonia wightii.

\section{Crude protein yield}

The overall effect of year on calculate total CP yield (t DM/ha $\times \% \mathrm{CP} \times 1000)$ was similar to that observed for total DM yield. Average annual irrigated legume $\mathrm{CP}$ yield was $1.0 \%$ more, and grass $\mathrm{CP}$ yield $2.9 \%$ less, than the respective rainfed $\mathrm{CP}$ yields. The total irrigated grass $\mathrm{CP}$ yields in eight harvests ranged from $1021 \mathrm{~kg} / \mathrm{ha}$ for $A$. gayanus to 2792 and $2794 \mathrm{~kg} / \mathrm{ha}$ for $P$. purpureum cvs Shika and Ngala, amounting to $44 \%, 55 \%$ and $56 \%$ of the total two-year CP yields.
Comparatively, the legume values ranged from $1634 \mathrm{~kg} / \mathrm{ha}$ for $D$. uncinatum, through $2701 \mathrm{~kg} / \mathrm{ha}$ for $S$. guianensis, to $3683 \mathrm{~kg} / \mathrm{ha}$ for $C$. cajan Acc UQ 50 and amounted to $49 \%, 51 \%$ and $54 \%$ of the total two-year CP yields.

\section{Experiment 2}

Dry matter yield

DM yields from one irrigated and one rainfed cropping per year of annual legumes, over 1975 and 1976, totalled slightly more than $40 \mathrm{t} /$ ha (lowest) for $V$. unguiculata or $G$. max var Congo Yellow and approximately $54.5 \mathrm{t} /$ ha (highest) for $G$. $\max$ var Potchefstroom 55 (Table 4). The overall year effect was non-significant but, regardless of year, average DM yield was significantly greater for irrigated cropping. The contribution of as much as $56 \%$ by irrigated cropping to total annual DM yield must have influenced the significant year $\times$ cropping interaction. Obvious DM yield differences between but not within croppings were demonstrated by the species.

Table 4. Dry matter yields ( $\mathrm{t} / \mathrm{ha}$ ) of irrigated and rainfed hay-suited annual legumes.

\begin{tabular}{|c|c|c|c|c|c|c|}
\hline \multirow[b]{2}{*}{ Cropping } & \multicolumn{3}{|c|}{1975} & \multicolumn{3}{|c|}{1976} \\
\hline & $\mathrm{Ir}^{+}$ & $\mathrm{Ra}$ & $\begin{array}{c}\text { Species } \\
\text { total }\end{array}$ & Ir & $\mathrm{Ra}$ & $\begin{array}{c}\text { Species } \\
\text { total }\end{array}$ \\
\hline G. max var Congo Yellow & 10.4 & 9.8 & 20.2 & 12.1 & 8.3 & 20.4 \\
\hline G. max var Malayan & 13.0 & 11.6 & 24.6 & 14.0 & 10.0 & 24.0 \\
\hline G. max var Potchefstroom 55 & 14.2 & 11.0 & 25.2 & 16.9 & 12.4 & 29.3 \\
\hline V. unguiculata Acc. IVu 1283 & 10.4 & 8.6 & 19.0 & 12.2 & 9.3 & 21.5 \\
\hline Cropping mean & 12.0 & 10.3 & 22.3 & 13.8 & 10.0 & 23.8 \\
\hline \multirow[t]{9}{*}{ LSD $(P=0.05)$} & $3.43 \mathrm{NS}$ & $3.34 \mathrm{NS}$ & $4.05^{*}$ & $4.36 \mathrm{NS}$ & $3.33 \mathrm{NS}$ & $4.59^{* * *}$ \\
\hline & \multicolumn{3}{|c|}{ LSD $(P=0.05)$ mean over two year } & & & \\
\hline & Year $(Y)$ & & $1.00 \mathrm{NS}$ & & & \\
\hline & Cropping (C) & & $1.00^{*}$ & & & \\
\hline & $\mathrm{Y} \times \mathrm{G}$ & & $1.42^{*}$ & & & \\
\hline & Species (S) & & $1.42^{*}$ & & & \\
\hline & $\mathrm{Y} \times \mathrm{S}$ & & $2.00 \mathrm{NS}$ & & & \\
\hline & $\mathrm{C} \times \mathrm{S}$ & & $2.00 \mathrm{NS}$ & & & \\
\hline & $\mathrm{Y} \times \mathrm{C} \times \mathrm{S}$ & & $2.83 \mathrm{NS}$ & & & \\
\hline
\end{tabular}

\footnotetext{
+ Ir, Ra $=$ Irrigated and rainfed croppings.
}

$\mathrm{NS}=$ Non-significant at $\mathrm{P}=0.05 ;^{*},{ }^{* *}=$ Significant at $\mathrm{P}=0.05, \mathrm{P}=0.01$. 


\section{Crude protein content}

The legumes averaged more CP contents in 1975 (Table 5), a reverse of the DM yield situation, although in neither case were the differences significant. Irrigated and rainfed $\mathrm{CP}$ contents compared favourably and the slightly higher value under irrigation were consistent among species in 1975 only.

\section{Crude protein yield}

Altogether, G. $\max$ vars Congo Yellow, Malayan and Potchefstroom 55 and V. ungui- culata produced estimated CP yields of 5582, 6429,7449 and $5830 \mathrm{~kg} / \mathrm{ha}$ to which irrigation contributed $56 \%, 57 \%$ and $56 \%$, respectively. Irrigated cropping was significantly superior to rainfed cropping and all the CP yield responses to irrigation tended to be better in 1976.

\section{Experiment 3}

\section{Seed yield}

G. max var Improved Pelican produced significantly the lowest total seed yield $(9207$

Table 5. Crude protein contents (\% dry matter) of irrigated and rainfed hay-suited annual legumes.

\begin{tabular}{|c|c|c|c|c|c|c|}
\hline \multirow[b]{2}{*}{ Species } & \multicolumn{3}{|c|}{1975} & \multicolumn{3}{|c|}{1976} \\
\hline & $\mathrm{Ir}^{+}$ & $\mathrm{Ra}$ & $\begin{array}{c}\text { Species } \\
\text { total }\end{array}$ & Ir & $\mathrm{Ra}$ & $\begin{array}{c}\text { Species } \\
\text { total }\end{array}$ \\
\hline G. max var Congo Yellow & 14.4 & 13.8 & 14.1 & 13.6 & 13.6 & 13.7 \\
\hline G. max var Malayan & 13.4 & 13.2 & 13.3 & 14.0 & 12.7 & 13.4 \\
\hline G. max var Potchefstroom 55 & 14.1 & 13.7 & 13.9 & 13.4 & 14.0 & 13.7 \\
\hline V. unguiculata Acc. IVu 1283 & 15.2 & 14.9 & 15.1 & 13.8 & 14.1 & 14.0 \\
\hline Cropping mean & 14.3 & 13.9 & 14.1 & 13.8 & 13.6 & 13.7 \\
\hline LSD $(P=0.05)$ & $3.74 \mathrm{NS}$ & $3.81 \mathrm{NS}$ & $2.22 \mathrm{NS}$ & $3.36 \mathrm{NS}$ & $3.36 \mathrm{NS}$ & $1.93 \mathrm{NS}$ \\
\hline
\end{tabular}

$+\mathrm{Ir}, \mathrm{Ra}=$ Irrigated and rainfed croppings.

$\mathrm{NS}=$ Non-significant at $\mathrm{P}=0.05$.

Table 6. Seed yields $(\mathrm{kg} / \mathrm{ha})$ of irrigated and rainfed perennial and annual legumes.

\begin{tabular}{|c|c|c|c|c|c|c|}
\hline \multirow[b]{2}{*}{ Cropping } & \multicolumn{3}{|c|}{1975} & \multicolumn{3}{|c|}{1976} \\
\hline & $\mathrm{Ir}^{+}$ & $\mathrm{Ra}$ & $\begin{array}{c}\text { Species } \\
\text { total }\end{array}$ & Ir & $\mathrm{Ra}$ & $\begin{array}{c}\text { Species } \\
\text { total }\end{array}$ \\
\hline C. cajan Acc 3D 8104 & 3562 & 2743 & 6305 & 3329 & 2827 & 6156 \\
\hline G. max var Improved Pelican & 2623 & 2260 & 4882 & 2375 & 1949 & 4324 \\
\hline G. $\max$ Acc $49-14$ & 3118 & 2733 & 5851 & 3505 & 2786 & 6291 \\
\hline G. $\max$ Acc M 216 & 3482 & 2958 & 6440 & 3290 & 2391 & 5681 \\
\hline V. unguiculata Acc IVu 1283 & 2951 & 2504 & 5455 & 3246 & 2347 & 5593 \\
\hline Cropping mean & 3147 & 2640 & 5787 & 3149 & 2460 & 5609 \\
\hline \multirow[t]{9}{*}{ LSD $(P=0.05)$} & $517.6^{*}$ & $510.7 \mathrm{NS}$ & $644.6^{*}$ & $479.7^{* *}$ & $627.8 \mathrm{NS}$ & $705.4^{* *}$ \\
\hline & \multicolumn{3}{|c|}{ LSD $(P=0.05)$ mean over two year } & & & \\
\hline & \multicolumn{2}{|c|}{ Year $(Y)$} & $145.0 \mathrm{NS}$ & & & \\
\hline & \multicolumn{2}{|c|}{ Cropping (C) } & $145.0^{* *}$ & & & \\
\hline & \multicolumn{2}{|c|}{$\mathrm{Y} \times \mathrm{G}$} & $205.0 \mathrm{NS}$ & & & \\
\hline & \multicolumn{2}{|c|}{ Species (S) } & $229.2^{* *}$ & & & \\
\hline & \multicolumn{2}{|c|}{$\mathrm{Y} \times \mathrm{S}$} & $324.2 \mathrm{NS}$ & & & \\
\hline & \multicolumn{2}{|l|}{$\mathrm{C} \times \mathrm{S}$} & $324.2 \mathrm{NS}$ & & & \\
\hline & \multicolumn{2}{|c|}{$\mathrm{Y} \times \mathrm{C} \times \mathrm{S}$} & $458.4 \mathrm{NS}$ & & & \\
\hline
\end{tabular}

+ Ir, Ra $=$ Irrigated and rainfed croppings.

$\mathrm{NS}=$ Non-significant at $\mathrm{P}=0.05 ;{ }^{*},{ }^{* *}=$ Significant at $\mathrm{P}=0.05, \mathrm{P}=0.01$. 
$\mathrm{kg} / \mathrm{ha}$ ) over the two years compared with the highest (12 $461 \mathrm{~kg} / \mathrm{ha})$ recorded for $C$. cajan Acc. 3D 8104 although the latter only differed marginally from other species yields. The meagre greater average 1975 seed yield was strongly influenced by $C$. cajan Acc. 3D 8104 and G. max Improved Pelican and M216 (Table 6). For both years irrigated cropping gave precisely similar total seed yields which significantly exceeded yields by the corresponding rainfed cropping. Species seed yield differences within season were significant for irrigated croppings and could be accounted for by the low $G$. max var Improved Pelican yield. On the average, irrigated $C$. cajan, G. $\max$ and $V$. unguiculata contributed $55 \%, 55 \%$ and $56 \%$ of the overall annual seed yields.

\section{Seed crude protein content}

Seed CP contents tended to have increased generally in 1976 (Table 7). Irrigated croppings produced seeds with significantly higher CP contents, an observation that was consistent for all legumes except $G$. max Acc. 49-14 in 1975 . The major species differences within cropping evolved from the inherently higher values for $G$. $\max$ which considerably outstripped those of $C$. cajan and V. unguiculata.

\section{Seed crude protein yield}

Since total seed yields were nearly uniform across the legumes (Table 6), the marked differences in calculated seed CP yields must have been sponsored by the seed CP contents, While $V$. unguiculata and $C$. cajan produced yields of 2536 and $2617 \mathrm{~kg} / \mathrm{ha}, G$. $\max$ yields varied from $3520 \mathrm{~kg} / \mathrm{ha}$ for va. Improved Pelican to 4746 and $4793 \mathrm{~kg} / \mathrm{ha}$ for Accs 49-14 and M 216 over the entire two-year period. The higher G. max Acc. 49-14 and V. unguiculata yields recorded in 1976 were a departure from the average species response trend. Irrigated cropping gave greater $\mathrm{CP}$ yields than rainfed croppings and accounted for 55 to $58 \%$ of average annual CP yields.

\section{Discussion}

This study suggested that, if irrigation assisted, the total annual herbage DM, CP and

Table 7. Seed crude protein contents ( $\%$ air-dry matter) of irrigated and rainfed perennial and annual legumes.

\begin{tabular}{|c|c|c|c|c|c|c|}
\hline \multirow[b]{2}{*}{ Species } & \multicolumn{3}{|c|}{1975} & \multicolumn{3}{|c|}{1976} \\
\hline & $\mathrm{Ir}^{+}$ & $\mathrm{Ra}$ & $\begin{array}{c}\text { Species } \\
\text { mean }\end{array}$ & Ir & $\mathrm{Ra}$ & $\begin{array}{c}\text { Species } \\
\text { mean }\end{array}$ \\
\hline C. cajan Acc 3D 8104 & 21.6 & 20.7 & 21.2 & 21.5 & 19.9 & 20.7 \\
\hline G. max var Improved Pelican & 38.2 & 37.5 & 37.9 & 39.4 & 37.7 & 38.6 \\
\hline G. $\max$ Acc $49-14$ & 38.8 & 39.0 & 38.9 & 40.1 & 38.1 & 39.1 \\
\hline G. $\max$ Acc M 216 & 40.2 & 38.1 & 39.2 & 40.5 & 38.9 & 39.7 \\
\hline V. unguiculata Acc IVu 1283 & 23.4 & 21.5 & 22.5 & 23.9 & 22.6 & 23.3 \\
\hline Cropping mean & 32.4 & 31.4 & 31.9 & 33.1 & 31.4 & 32.3 \\
\hline \multirow[t]{9}{*}{ LSD $(P=0.05)$} & $3.42^{* *}$ & $1.96 * *$ & $1.75^{* *}$ & $2.23 * *$ & $1.74^{* *}$ & $1.29 * *$ \\
\hline & \multicolumn{3}{|c|}{ LSD $(P=0.05)$ mean over two year } & & & \\
\hline & Year () & & $1.43 \mathrm{NS}$ & & & \\
\hline & Croppi & (C) & $1.43^{* *}$ & & & \\
\hline & $\mathrm{Y} \times \mathrm{G}$ & & $2.03 \mathrm{NS}$ & & & \\
\hline & Species & & $2.26 * *$ & & & \\
\hline & $\mathrm{Y} \times \mathrm{S}$ & & $3.20 \mathrm{NS}$ & & & \\
\hline & $\mathrm{C} \times \mathrm{S}$ & & $3.20 \mathrm{NS}$ & & & \\
\hline & $\mathrm{Y} \times \mathrm{C} \times$ & & $4.53 \mathrm{NS}$ & & & \\
\hline
\end{tabular}

$+\mathrm{Ir}, \mathrm{Ra}=$ Irrigated and rainfed croppings.

NS $=$ Non-significant at $\mathrm{P}=0.05 ;^{* *}=$ Significant at $\mathrm{P}=0.01$. 
seed yield of a number of promising perennial and annual forages/field crops could be at least doubled. Application of irrigation extended the growing season of the environment which represents the Nigerian subhumids with the approximately seven dry months a year and occasional drought incidents. In relation to earlier investigations conducted in Shika upland areas on herbage production from $P$. purpureum (AKINOLA, 1976), V. unguiculata (Akinola and Davies, 1978) and B. decumbens (AKINOLA, 1977), and seed production from the tested cultivars of $V$. unguiculata (Akinola and Davies, 1978) and G. max (AKINOLA, 1980) the present results have clearly identified water shortage as a principal constraint to the realisation of the potential yield and quality of adapted forages.

The need to use irrigation water judiciously was obvious. Although in the trials, $P$. purpureum and $B$. decumbens, among the grasses, responded best to irrigation water, the 20 23 t DM/ha obtained by de Leeuw (1972) from 100-day old $P$. purpureum established in mid-February at the same site indicated a higher growth rate explicable in terms of appropriate timing of irrigation and planting. Establishment in early January or commencement of irrigating forage regrowth as early as in December appeared, therefore, undesirable. This could be explained mainly as limitation on growth imposed by the low DecemberJanuary temperatures.

CP contents of grasses harvested in May were low and therefore associated with the long growth interval. Grass herbage thus obtained would have to be supplemented before feeding to livestock for at least body weight maintenance. The legumes on the other hand contained high CP levels throughout the year. However, since selection for irrigation must be based on material to support profitable meat and milk production ventures which rely not only on high CP content but also adequate herbage energy levels, the legumes to immediately recommend would be $C$. cajan and $S$. guianensis. Anthracnose disease was not encountered by $S$. guianensis under irrigation and wet season stand counts indicated less than five per cent mortality.

The large CP yields estimated are notable. While grass CP yields relied heavily on high DM yields, legume CP yields would be observed to have been strongly influenced by high CP contents. Most importantly, the yearround DM and CP yield stabilization experienced (MOLINE, ReHM and Nichols, 1974) certainly points out the significant role irrigation could play in overall agricultural output.

Although some responsive pure swards have been recognized, more work still needs to be done on grass-legume compatibility under irrigation for fuller exploitation of the climatic and adaphic environment and to support integration into other cropping systems. Since, currently, wheat and tomatoes are grown under irrigation, the investment cost of irrigating additional hectarages for combating feed shortage, improving livestock nutrition and survival and increasing leguminous grain production for human consumption (Addo, Akinola and Yusuf, 1987) and industrial purposes, should be minimal. However, this notwithstanding it is necessary to investigate the presumptive cost/benefit ratio of investing in irrigation facilities.

Animal population per se is of little importance and the major worry should concern the number of animal units (AU) per hectare. Since overgrazing stems from the sociological inclination of the Fulani herdsmen towards possessing large AU's than administering proper husbandry and feeding, these shortcomings would be substantially reduced by increased herbage availability. Shika research has produced encouraging results from a few of the forages examined for beef production from set stocking (OKEAGU and AKInOLA, 1982) cattle milk production when ensiled (Uмон, 1975), sheep dressing percentage in feedlot operations (ADU and BRINCKMAN, 1981) and goat feed cost/unit liveweight gain when pen fed (Iкнatua and Adu, 1984). Moreover, work there also suggested the possibility of animal genetic influences (Еносне, Adu and Olorunju, 1983) on the various an- 
imal performances obtained could not be overlooked. Consequently the need would arise for breeding and maintaining animals with genetic potential for production to efficiently complement any increased and stabilized plane of nutrition.

There is a dearth of information from Nigeria's irrigation schemes on soil water table and the amount of surface irrigation water required to avoid over-irrigation when optimum forage yield and quality are envisaged. Other areas that need further work include soil conservation, soil permeability assessment, potential of lining canals and ditches and of devices for drainage to prevent water-logging.

Acknowledgements. The authors are grateful to the staff of Pasture Agronomy Department and Biochemistry Laboratory, NAPRI, Shika, for plant sampling and analysis. The Directors of the Institute for Agricultural Research, Samaru and NAPRI are thanked for permission to publish this work, which forms part of a research programme approved by the Boards of Governors of both Institutes. J.O.A. would wish to thank the Board of Research of the Ahmadu Bello University, Zaria, for funding aspects of this study.

Finally, we would like to thank the Scientific Agricultural Society of Finland for including our study in their journal.

\section{References}

Addo, A.A.; Akinola, J.O. and Yusuf, H. 1987. Chemical composition and organoleptic properties of biscuits fortified with pigeonpea flour. Nigerian Food Journal 5: 24-29.

Adu, I.F. and Brinckman, W.L. 1981. Feedlot performance and carcass characteristics of sheep fed varying concentrate levels. Journal of Animal Production Research 1: 1-12.

Akınola, J.O. 1975. Preliminary assessment of forage legumes under irrigation for out-of-season dry matter and crude protein production. Samaru Agriculture Newsletter, 17: 62-67.

AKınOLA, J.O. 1976. Influence of spacing on performance of elephant grass (Pennisetum purpureum Schum.) during the year of establishment in the Northern Guinea Savanna of Nigeria. Nigerian Journal of Animal Production 3: 172-180.

AKInOLA, J.O. 1977. Establishment of Brachiaria/legume pastures in a Northern Guinea Savanna environment of Nigeria. Proceedings of the 13th International Grassland Congress. Leipzig, German Democratic Rebublic; Vol. II, 216-226.

Akınola, J.O. 1980. Soybean research at Shika, Northern Nigeria. Proceedings of the First Conference of Nigerian Soybean Scientists. Institute of Agricultural Research and Training, Moor Plantation, Ibadan, Nigeria, pp. 41-52.

Akinola, J.O. and Davies, J.H. 1978. Effects of sowing date on forage and seed production of 14 varieties of cowpea (Vigna unguiculata). Experimental Agriculture. 14: 197-203.

AOAC 1970. Official methods of analysis (11th Edition) Association of Official Analytical Chemists. Washington, D.C.
Doorn, J.W. van 1972. Recommendations on irrigated field lay-out in the Kano river project. Second Nigeria Irrigation Seminar, Zaria, Nigeria. Pp. 90-95.

Еносне, O.W., Adu, I.F. and OlorunJu, S.A.S. 1983. Milk yield, composition and lactation length in Yankasa crossbred ewes. Annual Report, National Animal Production Research Institute, Shika, Zaria, Zaria, Pp. 67-69.

IKнAтUA, U.J. and AdU, I.F. 1984. A comparative evaluation of the utilization of groundnut haulms and Digitaria smutsii by Red Sokoto goats. Journal of Animal Production Research 4: 145-152.

Kleinschmidt, F.H. and Skerman, P.J. 1977. Irrigation of tropics pasture legumes. In: Skerman, P.J. (ed) Tropical Forage legumes. FAO Plant Production and Protection Series No. 2, FAO, Rome. Pp. 150-158.

LeEuw, P.N. de 1972. Irrigated forage crops at Shika Research Station. Proceedings of the 2nd Nigeria Irrigation Seminar, Zaria. 152-156.

Moline, W.J.; Rehm, G.,W. and Nichols, J.T. 1974. Fertilizer responses of irrigated grasslands. In: Mays, D. (ed.) Forage fertilization. American Society of Agronomy. Madison, pp. 213-229.

OKeAgu, M.U. and AKInola, J.O. 1982. Effect of nitrogen rate on liveweight gain of White Fulani steers continuously grazed on signal grass (Brachiaria decumbens Stapf.) Journal of Animal Production Research 2: $91-98$.

OloRuntoBA, B.S. 1984. Towards self-sufficiency in food production in Nigeria. Public Lecture, Nigerian Institute of International Affairs, Lagos.

Steel, R.G.D. and Torrie, H.J. 1960. Principles and procedures of statistics, 2nd Ed. McGraw-Hill Book Co. Inc., New York, 426 pp. 
Uмон, J.E. 1975. A short-term comparison of the value of maize mucuna silage and elephant grass (Pennisetum purpureum) silage for milk production. Samaru Agricultural Newsletter, 17: 57-61.
Watt, B.K. and Merrill, A.L. 1963. Composition of foods - raw, processed, prepared. United States Department Agricultural Handbook No. 8190 pp.

Ms received October 10, 1989 